Ulasan Film

\title{
Tiga Babak Kekerasan dalam Marlina Si Pembunuh dalam Empat Babak
}

\section{Putu Agung Nara Indra Prima Satya}

Universitas Katolik Parahyangan, Bandung

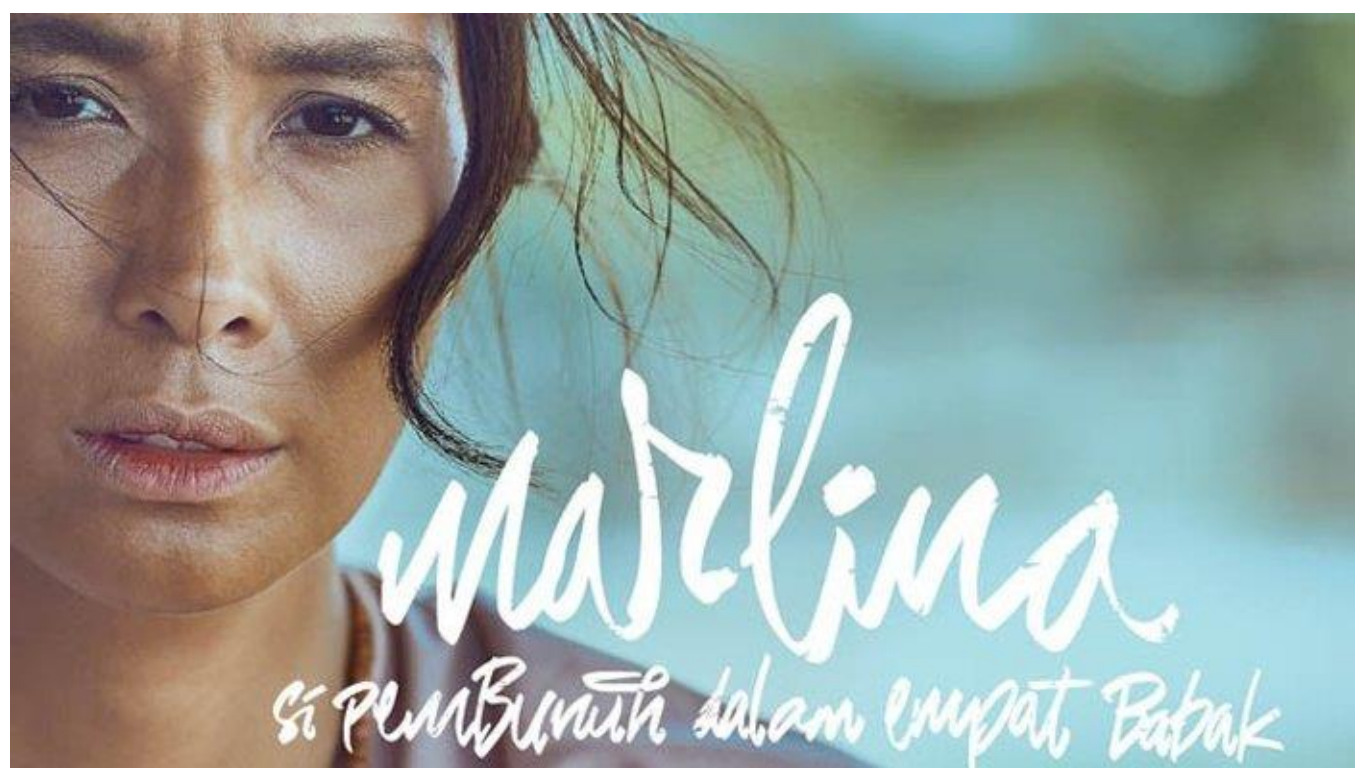

$\begin{array}{ll}\text { Durasi } & : \text { : } 93 \text { menit } \\ \text { Sutradara } & \text { : Mouly Surya } \\ \text { Ide cerita } & \text { : Garin Nugroho } \\ \text { Naskah } & \text { : Mouly Surya, Rama Adi, Garin Nugroho } \\ \text { Produser } & \text { : Rama Adi } \\ \text { Pemain } & : \text { Marsha Timothy, Dea Panendra, Yoga Pratama, Egy Fedly. } \\ \text { Tahun } & : 2017 \\ \text { Genre } & \text { : Drama }\end{array}$

Korespondensi Penulis:

Putu Agung Nara Indra PS, Universitas Katolik Parahyangan, Bandung E-mail: naraindra.prima@unpar.ac.id 


\section{Babak-Babak Kekerasan}

Apa yang terjadi ketika seorang wanita memenggal kepala laki-laki yang memperkosanya, lalu menenteng kepala itu ke Kantor Polisi? Tentu saja sebuah kehebohan. Lalu, secarik headline di koran lokal atau koran kuning? Atau, selarik tagar \#potongkepalasadis yang akan menempati puncak ke-viral-an di media sosial masa kini? Hal itu mungkin akan terjadi jika peristiwa itu berlangsung di kota-kota besar. Namun, bagaimana jika hal itu terjadi di daerah pinggiran nan eksotis selayaknya Sumba di Nusa Tenggara Timur? Mari kita tambahkan sedikit sabana, kuda, tebing-tebing dan pantai, isu feminisme, kain adat, serta sedikit dialek timur. Maka jadilah ia sebuah karya film yang digdaya di lingkaran kompetisi dunia.

Marlina Si Pembunuh dalam Empat Babak tentu saja tidak hanya berisi hal-hal banal itu semata (Bnd. Hardiman, 2016, 1-2). Film ini dibangun dengan sebuah premis yang sederhana: jika hukum tidak berjalan sebagaimana mestinya, maka bangkit dan lawanlah! Marlina adalah sebuah film tentang perlawanan, seperti yang diakui sendiri oleh Mouly Surya selaku sutradara. Perlawanan bisa mewujud ke dalam bentuk apa saja dan dilakukan oleh siapa saja. Kebetulan saja tokoh dalam film ini adalah seorang janda yang harus menghadapi para pencuri yang ingin mengambil semua termasuk kehormatannya sebagai seorang perempuan. Ia akhirnya memenggal kepala pemerkosanya dan meracuni komplotan pencuri lainnya dengan semangkuk sup ayam. Plot film selanjutnya makin berkembang seiring dengan perjalanan Marlina ke Kantor Polisi untuk melaporkan kejadian ini.

Perlawanan yang dilakukan oleh Marlina tak dapat dilepaskan dari kekerasankekerasan yang dialaminya. Bertolak dari konsep yang diperkenalkan oleh Johan Galtung, kekerasan dapat terjadi dalam tiga tataran: kekerasan fisik, kekerasan 
struktural, dan kekerasan kultural. Kekerasan fisik biasanya terjadi secara langsung dan menyasar kepada tubuh dan pikiran si korban. Kekerasan struktural berakar dari struktur ekonomi-sosial-politik yang membuat seseorang tidak mampu mengoptimalkan potensi dirinya. Sedangkan kekerasan kultural bersumber dari budaya dan adat yang menghalangi aktualisasi diri seseorang(Galtung, 2002). Di dalam tiap babak film ini, Marlina dan tokoh-tokoh lainnya khususnya Novi akan bergelut dengan ketiga jenis kekerasan ini. Hal ini ironisnya muncul akibat posisi mereka sebagai perempuan dalam budaya Sumba yang lekat dengan jeratan patriarki (Bnd. Lubis, $1988,150)$.

Kita tidak dapat menepikan napas feminisme dalam film ini (Rubianti, 2017). Bahkan, perlawanan yang dilakukan oleh Marlina pun terasa sangat 'perempuan'. Berbeda dengan film-film bertema balas dendam lainnya, dimana sang tokoh utama akan beradu fisik dengan tokoh antagonis dalam klimaks yang berdarah-darah, perlawanan Marlina sebenarnya bersumber dari hal-hal yang ditimpakan sebagai 'kodrat'nya sebagai perempuan.

Pertama, keberhasilan Marlina memenggal Markus bukan diperolehnya dari adu fisik yang keras layaknya dalam film-film bertema balas dendam ala koboi western atau film-film India yang sangat macho. Ia justru melakukannya saat Markus tengah lengah dan terlena ketika berhubungan badan dengan Marlina. Kedua, para komplotan pencuri teman-teman Markus juga dibunuh bukan dengan parang atau perkelahian. Mereka tewas karena memakan sup ayam hasil masakan Marlina yang telah dibubuhi racun buah (kersen?). Dua sarana yang dipakai oleh Marlina dalam membunuh pria-pria itu, seks dan masakan, adalah produk utama dari dua tempat 'kodrati' perempuan: ranjang dan dapur. 
Pada babak pertama film, Markus dan kawanannya berupaya menggiring Marlina ke dalam posisi inferior ketika mereka meminta Marlina menyiapkan makan malam sebelum melakukan persetubuhan. Akhirnya, inferioritas itu justru memberikan celah bagi Marlina untuk mengambil nyawa mereka. Marlina sempat membubuhkan racun ke dalam sup ayam yang dimasaknya. Begitu pun yang terjadi saat Markus tengah bersetubuh dengan Marlina. Perhatiannya terpecah oleh kenikmatan sehingga alpa menyingkirkan parangnya dari tempat tidur. Di sisi lain, pembelaan diri Marlina juga tidak bisa dikatakan sebagai sesuatu yang spontan. Ia bisa saja telah merencanakan pembunuhan-pembunuhan itu. Kita dapat melihatnya dari buah racun yang sudah disiapkannya di dapur. Laku pembunuhan yang dijalankan oleh Marlina adalah sesuatu yang terencana, sehingga ia tidak bisa dipandang sebagai protagonis yang murni tak bersalah.

Babak kedua dan ketiga dari film ini menceritakan tentang perjalanan Marlina ke kantor polisi sambil membawa kepala Markus. Di tengah perjalanan, ia ditemani oleh dua orang: Novi dan sosok tanpa kepala yang membawa sebuah alat musik seperti ukulele. Kita tidak tahu pasti apa yang diharapkan Marlina dari polisi. Apakah ia akan menyerahkan dirinya? Jika iya, mengapa harus menyerahkan diri? Marlina bersikeras bahwa dirinya tidak bersalah atas pembunuhan itu. Bahkan, Marlina sampai menolak anjuran Novi untuk pergi ke gereja alih-alih ke Kantor Polisi. Novi menyarankan Marlina untuk mengaku dosa di gereja, tetapi Marlina menampiknya mentah-mentah. Apakah itu berarti Marlina lebih mempercayai institusi keamanan negara (polisi) dibandingkan institusi keagamaan (gereja) yang juga memiliki pengaruh besar dalam struktur sosial masyarakat Sumba? 
Untuk mencari jawabannya, kita harus kembali kepada sejarah awal film ini. Naskah film Marlina sebenarnya merupakan ide cerita dari sineas Garin Nugroho. Ia sudah beberapa kali pergi ke Sumba dan sempat membuat dua film yaitu Surat untuk Bidadari(Nugroho, 1994), dan Angin Rumput Savanah(Nugroho, 1997). Ketika berada di Sumba, Garin sempat melihat seseorang menenteng kepala manusia dan membawanya ke kantor polisi. Ternyata, orang itu baru saja terlibat duel, memenggal kepala lawannya, lalu menyerahkan diri ke polisi. Kejadian seperti ini ternyata cukup jamak ditemui di Sumba. Polisi dianggap sebagai perwakilan struktur dan hukum negara. Di sisi lain, konsekuensi dari sebuah pembunuhan seringkali lebih berat dari sisi hukum dibandingkan hanya dari sisi moral. Hal ini membuat para pembunuh lebih memilih untuk menyerahkan diri ke Kantor Polisi dibandingkan pergi ke institusi lain. Polisi juga dapat melindungi si pembunuh dari upaya balas dendam yang dilakukan oleh keluarga korban.

Kedatangan Marlina ke kantor polisi pada akhirnya tidak berjalan sesuai harapan. Ia harus bertemu dengan sebuah institusi struktural yang dingin, tak acuh, kaku, dan nihil empati. Marlina dipaksa menunggu para polisi bermain tenis meja sebelum melaporkan pencurian Markus dan kawanannya. Polisi yang menginterogasinya malah berbalik menyalahkan Marlina atas perkosaan itu. Mereka tidak dapat melakukan apapun terhadap kejahatan yang dialami oleh Marlina. Sebuah gambaran yang tidak mengherankan bagi kita semua yang terbiasa hidup di Indonesia dimana kekerasan struktural masih merajalela. Struktur yang diharapkan dapat menciptakan keadilan dan ketertiban justru menjadi pihak yang melanggarnya. Manusia hanyalah sekumpulan tubuh administratif yang dikodifikasikan ke dalam angka semata. Atau, dalam kasus Marlina, polisi yang diharapkan menciptakan solusi malah berujung menambah polusi. 
Babak ketiga dalam film Marlina juga memuat gambaran atas kekerasan kultural, khususnya yang menimpa Novi. Dalam film ini, Novi diceritakan sebagai perempuan yang telah hamil 10 bulan tetapi belum juga melahirkan. Suaminya, Umbu, menuduh ini terjadi karena bayinya sungsang akibat Novi berhubungan badan dengan lelaki lain. Umbu justru menyalahkan Novi yang asyik masyuk dengan lelaki lain sementara Umbu bekerja keras membanting tulang, sebuah pandangan khas budaya patriarki yang meminggirkan posisi perempuan sebagai satu-satunya pihak yang bertanggung jawab terhadap proses kehamilan dan melahirkan.

Sub-plot yang menceritakan tentang Novi dan masalahnya memberikan variasi yang cukup menarik untuk melengkapi plot utama yang dimainkan oleh Marlina. Salah satu fragmen yang cukup menarik terjadi saat Novi terlibat perbincangan dengan Yohana di dalam truk. Ketika Novi curhat tentang tuduhan Umbu bahwa ia berhubungan badan dengan pria lain sehingga bayinya sungsang, Yohana membantahnya dengan tegas. Ia bahkan berseloroh bahwa bayi di Rahim Novi belum keluar karena ia kurang berhubungan badan dengan suaminya. Yohana percaya bahwa seorang anak bisa lahir lewat Rahim ibunya atas bantuan ayah yang membantu 'membuatkan jalan' bagi anaknya lewat hubungan seksual ketika masa kehamilan sudah menua. Pria dan wanita pada akhirnya harus bekerja sama untuk memberikan jalan bagi kehidupan yang baru. Dalam perkara supremasi perempuan, tokoh Yohana adalah perempuan yang paling kuat dalam film ini. Ia menunjukkan bahwa posisinya sangat penting dalam keluarganya sehingga tanpa dia keponakannya tidak akan jadi menikah.

Pertanyaan terakhir yang mengemuka ketika memasuki babak keempat dari film ini adalah apakah Marlina (dan Novi) dapat keluar dari belenggu ketiga babak kekerasan yang muncul selama plot berlangsung? Pada akhirnya, upaya yang 
dikerahkan Marlina dan Novi tidaklah cukup untuk memerangi ketiganya. Mereka hanya sanggup untuk melawan kekerasan langsung, itu pun dilakukan dengan melakukan kekerasan yang sama. Kekerasan langsung memang adalah bentuk kekerasan yang paling mudah untuk diidentifikasikan, sehingga relatif paling mudah dilawan. Sayangnya, perlawanan terhadap kekerasan langsung seringkali dilakukan dengan melakukan kekerasan serupa. Akhirnya, terciptalah lingkaran kekerasan yang tidak ada ujungnya.

Kekerasan langsung hanyalah merupakan puncak dari gunung es dari struktur kekerasan yang kita alami (Anisa \& Santoso, 2020). Sifatnya nyata, bisa diukur, bisa dilihat, dan bisa dirasakan. Di sisi lain, kekerasan struktural dan kekerasan kultural sifatnya lebih abstrak, laten, tetapi menyimpan bahaya yang jauh lebih besar. Dalam konteks film ini, Marlina dan Novi menempuh jalur yang berbeda. Bagi Marlina, kekerasan langsung yang dialaminya di awal film yang memaksanya harus berurusan dengan kekerasan struktural dan kultural di kantor polisi. Jika Markus tidak datang dan memperkosanya, ia mungkin tidak harus berurusan dengan polisi yang ikut-ikutan melecehkan posisinya sebagai korban. Sebaliknya kekerasan langsung yang dialami Novi dari suaminya justru merupakan tindakan yang berhulu dari prasangka yang lahir dari kepercayaan adat bahwa bayi yang sungsang pasti lahir dari hubungan di luar nikah.

Seluruh kekerasan dalam film ini berbalut dengan latar belakang Sumba yang cantik nan eksotis tetapi juga gersang dan keras. Sebuah kontradiksi yang nampak jelas di beberapa bagian. Proses syuting Marlina dilangsungkan di kabupaten Sumba Timur, khususnya di daerah-daerah seperti Mondu dan Warinding yang terletak tidak jauh dari ibukota Waingapu. Sumba belakangan ini memang menjadi daerah tujuan baru bagi 
pengambilan gambar dari film-film Indonesia. Setelah Garin Nugroho memulai eksplorasinya atas Sumba melalui film "Surat untuk Bidadari" (Nugroho, 1994)dan “Angin Rumout Savanah"(Nugroho, 1997), generasi sineas berikutnya ikut mengambil latar di pulau ini lewat "Pendekar Tongkat Emas"(Isfansyah, 2014), "Susah Sinyal" (Prakasa, 2017), “Atambua 39 Derajat Celsius” (Riza, 2012), dan “Humba Dreams” (Riza, 2019). Semoga film-film yang kelak mengeksplorasi daerah-daerah baru seperti Sumba tidak hanya gencar menampilkan mereka sebagai latar semata, tetapi juga memotret gejala-gejala sosial yang terdapat di wilayah itu.

\section{Referensi}

Anisa, \& Santoso, M. B. (2020). Advokasi Pekerja Sosial Terhadap Korban Kekerasan Seksual Terhadap Perempuan Dalam Situasi Bencana. 208-217.

Galtung, J. (2002). Kekerasan Kultural. In Wacana Kekerasan dalam Masyarakat Transisi (IX). Insist.

Hardiman, B. F. (2016). Heidegger dan Mistik Keseharian. Kepustakaan Populer Gramedia.

Isfansyah, I. (2014). Pendekat Tongkat Emas.

https://www.youtube.com/watch?v=FgwNwlpDB1M\&lc=Ugi5Jz6IH5qej3gCoAEC

Lubis, M. (1988). Menggapai Dunia Damai. Yayasan Obor Indonesia.

Nugroho, G. (1994). Surat untuk Bidadari. https://www.youtube.com/watch?v=kDT0Pvc6Aro

Nugroho, G. (1997). Angin Rumput Savana.

https://www.youtube.com/results?search_query=Angin+Rumput+Savanah+(199)

Prakasa, E. (2017). Susah Sinyal.

Riza, R. (2012). Atambua 39 Derajat Celsius.

Riza, R. (2019). Humba Dreams.

Rubianti, F. (2017). Semangat feminisme dalam pemikiran Cak Nur. Beritagar.Id. 